office/2011/11/12/remarks-president-obama-apec-ceo-business-summit-qa [Accessed: 16th November 2012]

27. FERNANDEZ, JOSE W. (2013). Partnering with Thailand on Regional Economic Integration Remarks Jose W. Fernandez Assistant Secretary, Bureau of Economic and Business Affairs AmCham Bangkok, Thailand, February 27, 2013. U.S. Department of State [Online]. Available from: http://www.state.gov/e/eb/rls/rm/2013/206025.htm [Accessed: 2nd March 2013]

28. HIKOTANI, TAKAKO (2017). Trump's Gift to Japan Time for Tokyo to Invest in the Liberal Order. Foreign Affairs [Online]. Available from: https://www.foreignaffairs.com/articles/asia/2017-0815/trumps-gift-japan?cid=int-rec\&pgtype=art [Accessed: 16th November 2017]

Надійшла до редколегії 10.09.2017

Nataliya Gorodnia, Dr. habil. (history), Professor, Taras Shevchenko National University of Kyiv, Kyiv

\title{
U.S. MULTILATERAL TRADE STRATEGIES IN ASIA PACIFIC: FROM G. H. W. BUSH TO D. TRUMP
}

\begin{abstract}
The paper studies U.S. multilateral regional trade strategies in Asia Pacific during G. H. W. Bush, B. Clinton, G. W. Bush, B. Obama and D. Trump administrations. Based on a study of primary and secondary sources and a comparative analysis, the research defines continuity and differences in the administrations' policies in implementation of multilateral regional trade strategies, as well as their impact on regional economic integration and U.S. role in it. The study provides a background for better understanding of D. Trump's actions to withdraw U.S. from multilateral trade agreement Trans-Pacific Partnership. As a result of the research, we concluded the following. First, Asian Pacific region occupied higher priority in the U.S. trade policy agenda during Democratic Party administrations of B. Clinton and B. Obama than Republican administrations of G.H.W. Bush and G.W.Bush. Second, Democratic administrations used multilateral trade strategies and institutions more effectively not only with economic purposes but also as tools to engage U.S. in the shaping of regional architecture. Bilateral trade negotiations with regional nations were more preferable during Republican administrations and after economic crises. Thus, on the one hand, D. Trump's trade policy partly correlates with previous Republican Party administrations. On the other hand, it contradicts trade strategies of all his predecessors, because they used foreign trade not only for trade purposes, but also for preserving and strengthening U.S.' impact in East Asia with "soft power" tools. D. Trump's trade policy, which is aimed at reaching short-termed goals, endangers American strategic interests and promotes China's regional influence.

Key words: U.S., East Asia, Asia Pacific, foreign trade strategies, G. H. W. Bush, B. Clinton, G. W. Bush, B. Obama and D. Trump administrations.
\end{abstract}

\section{УДК 94 (7) 327}

http://doi.org/10.17721/2521-1706.2018.04.117-125

Ірина Зубаренко, кандидат історичних наук, доцент, Одеський національний університет ім. I. І. Мечникова

\section{АМЕРИКАНСЬКО-СГИПЕТСЬКІ ВІДНОСИНИ ПІСЛЯ АРАБСЬКОЇ ВЕСНИ}

Анотація. Дану статтю присвячено розвитку американсько-єгипетських відносин після Арабської весни, що відбулась взимку 2010 року і призвела до змінення політичної, економічної і сочіальної ситуачії в Арабській Республічуі Сгипет. 
Єгипет $\epsilon$ найбільш густонаселеною арабською краӥною. I хоча він вже неспроможний відігравати роль лідера в Арабському світі, досі залишається впливовою країною регіону завдяки своєму історичному спадку.

Нинішній адміністраџія США висловила великі сподівання стосовно американськоєгипетських відносин, які зазнали певного напруження. Однак, існує ризик того, щзо співпрачя з офіційним Каӥром може зазнати репресивних тенденцій, поставивши американсько-єгипетські відносини на хиткий фундамент протягом наступних років.

У статті висвітлено авторське бачення подій на основі першоджерел, щяо їх здебільшого було представлено у західній пресі. Текст статті, в иілому, побудовано на основі хронологічного аналізу ситуачії, яка мала місие у історї взаємин двох країн. Попри зафіксовані історичні факти, оприлюднені в контексті певних подій, авторка статті залишає за собою право на власний аналіз тогочасних реалій.

Ключові слова: Арабська весна, американсько-єгипетські відносини, президент, демократія, вибори, Сгипет, США.

Єгипет завжди викликав великий інтерес у США завдяки його стратегічному розташуванню, демографічній ситуації i дипломатичній діяльності. Під єгипетським контролем знаходиться Суецький канал, через який щорічно проходить 8\% усіх світових морських перевезень. В свою чергу уряд АРЄ сприяє проходженню десятків американських військово-морських кораблів через Суецький канал, що надає стратегічну перевагу силам США у проведенні певних операцій в Середземному морі та у басейні Індійського океану.

3 точки зору демографії Єгипет з населенням 94,6 млн. душ на сьогодення є найбільш густонаселеною арабською країною. I хоча Єгипет вже неспроможній відігравати роль лідера в Арабському світі, як це було в минулому, він досі залишається впливовою країною регіону завдяки своєму історичному спадку i активній діяльності 3МІ. У Каїрі знаходиться штаб-квартира Ліги Арабських Держав, до складу якої входять 22 країни, і університет Аль-Азгар, який вважається найсоліднішим постійно діючим вищим учбовим закладом у вихованні мусульманського духовенства.

На додаток, мирний договір Сгипту з Ізраїлем, підписаний у 1979 році за посередництвом США, залишається одним 3 найважливіших дипломатичних досягнень у прагненні встановити арабсько-ізраїльський мир.

Після підписання зазначеного договору Конгрес США прийняв рішення щорічно виділяти 1,3 млрд. амер. доларів на військову допомогу Єгипту і 250 млн. амер. доларів у якості економічної допомоги [1]. Таким чином, Єгипет перетворився на реципієнта №2 (після Ізраїлю) американської допомоги на Близькому Сході. Слід зазначити, що сам договір не містив жодних зобов'язань 3 боку США про надання допомоги Ізраїлю і Сгипту, проте офіційний Вашингтон вирішив фінансово підтримувати обидві країни 3 метою забезпечення регіонального балансу сил та зміцнення співробітництва в галузі безпеки.

Арабська весна у Єгипті, яка по суті стала революцією, розпочалась 25 січня 2011 року і призвела до зміни влади та суттєвих внутрішніх потрясінь. У перші дні Арабської весни в АРС президент США Барак Обома закликав офіційний Каїр утримуватись від насилля, оскільки, за його словами, народ має право на свободу проведення мирних демонстрацій, право на свободу слова i право власноруч формувати своє майбутнє. Також американський лідер закликав тогочасного президента країни Хосні Мубарака скасувати обмеження доступу до Інтернету, а 
демонстрантів збиратись тільки на мирні демонстрації, оскільки насильство та руйнування не приведуть до демократичних перевтілень [2].

Після провалу спроби утримати владу в своїх руках Хосні Мубарак йде у відставку. 11 лютого 2011 року влада в країні переходить до Вищої ради військових сил під керівництвом міністра оборони і військової промисловості АРЕ фельдмаршала М. Х. Тантаві. У послідуючі місяці після відставки Хосні Мубарака адміністрація Барака Обами зі свого боку зосереджується на встановленні контактів 3 новими політичними силами у Єгипті заради забезпечення плавного переходу до демократії і стабілізації економічного стану, однак Арабська весна сколихнула в країні хвилю антиамериканізму.

29 грудня 2011 року єгипетські військові і поліція провели рейди з підозрами у незаконному закордонному фінансуванні по 17 відділенням місцевих та іноземних неурядових організацій, серед яких були Міжнародний республіканський інститут (IRI), Національний демократичний інститут (NDI), Freedom House i німецький Фонд Конрада Аденауера [3].

Сполучені Штати сприйняли цю акцію як порушення демократичних цінностей i погрожували Єгипту припинити надання щорічної військової i економічної допомоги, проте єгипетський уряд проігнорував погрози з боку США. 43 членам неурядових організацій, у тому числі Сему Лахуду, голові єгипетського офісу Міжнародного республіканського інституту (IRI) і Ненсі Окайлі, директору Freedom House у Сгипті було пред'явлено звинувачення в підриві політичної стабільності, вербуванні агентів серед єгиптян і співпраці з розвідками США та Ізраїлю. Однак 1 березня 2012 року голова Апеляційного суду Каїра Абдул Мойз Ібрагім постановив зняти зі звинувачуваних заборону на виїзд 3 країни, зобов'язавши кожного з них заплатити штраф розміром приблизно в 332 тис. амер. доларів [4].

У той період один 3 провідних фахівців Міжнародного науководослідницького центру Вудро Вільсона Арон Девід Міллер висловлював припущення, що у разі поповнення складу нового уряду АРС ісламістами, такими як члени організації «Брати-мусульмани», єгипетсько-американська співпраця 3 питань тероризму помітно скоротиться. «Це одна з галузей, де ви відчуєте певне засмучення», - констатував Міллер. Але далеко не всі експерти погоджувались 3 його думкою. Роберт Мейлі, директор програми «Близький Схід / Північна Африка» 3 Міжнародної кризової групи вважав «Братів-мусульман» вагомим політичним і культурним угрупуванням, спроможним покласти кінець безладу в країні. «Їх прихід до влади в Єгипті стане своєрідним тестом на здібність американської адміністрації знаходити спільну мову 3 ненасильницьким політичним ісламом, що може ознаменувати поворотний момент в історії взаємин», - апелював Мейлі. Інші політики і дослідники стверджували, що ще рано пророкувати за яким сценарієм усе відбуватиметься. Колишній секретар адміністрації Джорджа Буша 3 Міністерства внутрішньої безпеки Том Рідж застерігав: «Ця гра не закінчилась, і ми навіть не знаємо, у що саме граємо» [5].

24 червня 2012 року на президентських виборах у Єгипті перемогу здобув лідер «Братів-мусульман» Мохамед Мурсі. Він отримав 51,73\% голосів і всього на кілька відсотків обійшов свого суперника, колишнього прем'єр-міністра АРС Ахмеда Шафіка, за якого проголосувало 48,27\% виборців. Заради збільшення своєї популярності серед єгиптян Мурсі вийшов 3 організації «Брати-мусульмани» та покинув ряди Партії свободи і справедливості. 30 червня 2012 року М. Мурсі 
вступив на посаду президента Сгипту. Білий дім привітав ісламістського лідера, назвавши цю подію визначною віхою у переході країни до демократії. Б. Обама підкреслив, що «Сполучені Штати продовжуватимуть підтримувати перехід Сгипту до демократії та стоятимуть на боці єгипетського народу, який доклав чималих зусиль заради здійснення революції» [6]. На додаток він відверто висловив свою зацікавленість у співпраці з новообраним президентом М. Мурсі на основі взаємної поваги та 3 метою подальшої реалізації спільних інтересів між США і Єгиптом.

14 липня 2012 року в Сгипті перебувала з офіційним візитом держсекретар США Гілларі Клінтон. Під час спілкування з президентом АРС М. Мурсі вона зазначила: «Ми хочемо бути гарним партнером для Єгипту і цілком підтримуємо демократію, що їі було досягнуто мужністю та жертвою єгипетського народу, але попереду ще багато роботи. Я гадаю, що парламентські та конституційні питання мають вирішуватись виключно єгиптянами. Водночас я з нетерпінням чекатиму на розгляд питань 3 національної безпеки під час зустрічі з фельдмаршалом Тантаві». Окрім того Г. Клінтон додала, що уряд США вибачає Єгипту заборгованість розміром у 1 млрд. амер. доларів і надає 280 млн. амер. доларів для економічного розвитку країни [7].

Але ж попри зусилля 3 боку офіційних сторін антиамериканські настрої в Єгипті не згасали. В опитуванні, проведеному Вашингтонським науководослідницьким центром, було з'ясовано, що понад $60 \%$ єгиптян прагнуть, щоб закони нового уряду чітко відповідали приписанням 3 Корану; така позиція відверто свідчила про втрату Сполученими Штатами контролю над становленням демократії у цій країні.

11 вересня 2012 року єгипетські протестувальники штурмували посольство США в Каїрі, зірвали 3 його будівлі та пошматкували державний прапор, замінивши його прапором 3 ісламською символікою. Свої дії вони охарактеризували як відповідь на вихід у американський прокат фільму, який на їх думку принижує гідність мусульманського пророка Мохамеда.

Реакція президента Обами на цю акцію була доволі дипломатичною. «Я не думаю, що усіх єгиптян можна вважати нашими союзниками, але ми i не сприймаємо їх як ворогів. Новий уряд на чолі з М. Мурсі наразі перебуває у пошуку власного шляху до демократії», - констатував американський лідер. Дипломатичний кореспондент BBC News Джонатан Маркус зауважив, що «настороженість Б. Обами щодо нових реалій в Єгипті жодним чином не засмутить нового президента країни, оскільки той добре усвідомлює, що його політичне минуле на тлі керівництва організацією «Брати мусульмани» провокує скептичне ставлення до стратегічних цілей США в регіоні. Окрім того, в Сполучених Штатах усе яскравіше спостерігалось суспільне невдоволення тим, що Близький Схід виявився «невдячним» офіційному Вашингтону за підтримку під час подій Арабської весни» [8].

22 листопада 2012 року М. Мурсі підписав декларацію, яка позбавляла суди права розпуску Верховної палати парламенту та Конституційної асамблеї, а також дозволяла президенту країни видавати будь-які декрети, спрямовані на захист революції, що їх не може бути оскаржено в суді. Дії Мурсі викликали обурення 3 боку опозиції, яка обвинувачувала президента в узурпації влади та відновленні диктатури. Внаслідок, 25 січня 2013 року у Єгипті знову спалахнули протести, рушійною силою яких став Чорний блок. Президент М. Мурсі ввів надзвичайний 
стан в трьох містах: Порт-Саїді, Суеці та Ісмаїлії, але це не врятувало його від подальших загальних невдоволень, що призвели до військового перевороту 4 липня 2013 року на чолі з міністром оборони і військової промисловості, верховним головнокомандуючим збройних сил АРЄ Абдулем-Фаттахом ас-Сici. Президента М. Мурсі було заарештовано.

Адміністрація Б. Обами осудила єгиптян за боротьбу з політикою колишнього лідера «Братів мусульман», скасувавши проведення сумісних військових маневрів, i припинила надання збройним силам АРЕ реактивних винищувачів Ф-16 та ударних вертольотів АН-64 «Апач», що певним чином, негативно вплинуло на взаємини між двома країнами.

Тимчасовим президентом було призначено голову Конституційного суду АРЕ Адлі Мансура, але країною знову прокотилась хвиля масових невдоволень, що призвело до вуличних бійок, під час яких 14 серпня 2013 року загинуло 638 людей, у тому числі і 43 поліцейських [9].

18 січня 2014 року тимчасовий уряд ратифікував нову конституцію APE у наслідок референдуму, проведення якого підтримало 98,2\% виборців, а 26 березня Абдуль-Фаттах ас-Сісі пішов у відставку, оголосивши, що він висуватиме свою кандидатуру на посаду голови країни. На виборах, які проходили у період з 26 по 28 травня 2014 року, 96\% єгиптян віддали свій голос на користь Абдуля-Фаттаха ac-Сici. Слід зазначити, що ці вибори було проведено без участі партії «Свобода i справедливість» та «Братів мусульман». 8 червня 2014 року Абдуль-Фаттах ас-Сісі склав присягу президента АРС.

3 перших кроків свого президентства Абдуль-Фаттах ас-Сісі намагався слідувати збалансованій зовнішній політиці, незалежної від регіональних інтересів Сполучених Штатів, Європейського Союзу та держав Перської затоки. Однак націоналістичні єгипетські почуття завжди натикались на політичними реалії, що призводили країну до залежності від іноземного спонсорування.

Вже через два тижні після того, як Абдуль-Фаттах ас-Сici став президентом AРС, Каїр відвідав держсекретар США Джон Форбс Керрі. Провівши переговори 3 новим президентом АРЕ, Д. Керрі наголосив, що Сполучені Штаті завжди готові надавати підтримку єгипетському народові заради захисту його прав $\mathrm{i}$ свобод. «Наразі Єгипет отримав шанс для високих ставок і великих можливостей. Після трьох складних років перехідного періоду в Сгипті адміністрація США досі глибоко вірить у те, що ця країна досягне бажаного успіху», - констатував Д. Керрі [10].

Наслідком зазначених переговорів стало поновлення щорічної фінансової допомоги АРС з боку Сполучених Штатів у розмірі 1,3 млрд. амер. доларів, що іiі планувалось спрямувати здебільшого на сплату існуючих оборонних контрактів. Серйозність своїх намірів щодо зміцнення стратегічного партнерства з Сгиптом офіційний Вашингтон довів і протягом наступного візиту держсекретаря США Д. Керрі до Каїру у серпні 2015 року. Під час спілкування зі своїм єгипетським колегою Самехом Шукрі Джон Керрі запевнив, що США «надалі проводитимуть тренінги для єгипетських військових, оскільки ті щиро прагнуть зміцнити потенціал своєї країни» [11].

У вересні 2014 року Абдуль-Фаттах ас-Сісі відвідав США 3 візитом до Генеральної Асамблеї ООН в Нью-Йорку. І хоча його офіційно не запрошували, це турне стало гарною нагодою для пожвавлення відносин між двома країнами. 
Широка медіа кампанія розповсюдила рекламні щити по всьому місту, вітаючи єгипетського президента гаслом «Новий Сгипет: мир, процвітання та підйом».

Своєрідним сюрпризом для офіційного Вашингтону став курс АбдуляФаттаха ас-Сісі на зближення з Росією. Під час першого офіційного візиту до Москви у серпні 2014 року його натхненно вітав російський колега В. Путін, який оголосив про підтримку нового єгипетського режиму. Коли Путін відвідав Каїр у лютому 2015 року, його на червоному килимі з усіма почестями зустрічали вищі військові чиновники АРС. Такі теплі взаємини призвели до того, що Росія домовилась про створення першої атомної електростанції у Сгипті, а також обидві сторони обговорили, як зменшити вартість долара у двосторонніх торгах в обхід інтересів Заходу.

Попри активність Абдуль-Фаттаха ас-Сісі на зовнішньополітичній арені, прояви тероризму на єгипетській території, у тому числі i на Синайськім півострові, не вщухали. Деякі конгресмени почали закликати адміністрацію США припинити надання АРЕ фінансової допомоги. Зі свого боку Білий дім запевнив, що про це не може бути й мови, але починаючи 32018 фінансового року, Сполучені Штати надаватимуть Єгипту допомогу виключно для вирішенні наступних питань: боротьби з тероризмом, безпеки кордонів, стабілізації ситуації на Синайськім півострові, спокою на морських кордонах i заради підтримки потенціалу збройних сил країни [12].

3 кінця 2016 року, американсько-єгипетські відносини ознаменувались шквалом двосторонніх обмінів візитами. Міністр закордонних справ АРС Самех Шукрі відвідав Вашингтон тричі, починаючи 3 листопада 2016 року. Певною ознакою покращення взаємин між двома країнами на той час можна вважати офіційний візит до Єгипту голови Центрального командування збройних сил США, генерала-майора Джозефа Л. Вотеля наприкінці лютого 2017 року. Наслідком цього візиту стала домовленість про відновлення між США і Єгиптом дворічної багатонаціональної навчальної програми для військових «Bright Star», спрямованої на покращення навиків і зміцнення потенціалу збройних сил. Враховуючи політичні потрясіння в Сгипті, що до їх призвела Арабська весна, президент Б. Обама призупинив участь США у зазначеній програмі після того, як в липні 2013 року колишнього президента АРЄ М. Морсі було заарештовано.

Коли 20 січня 2017 року президентом США став Дональд Трамп, уряд АРС висловив великі сподівання на те, що американсько-єгипетські відносини, які зазнали певного напруження під час трьох років перебування за кермом влади Барака Обами, буде покращено. Однак, згідно прогнозам Центру Американського прогресу, що їх було виказано станом на лютий 2017 року, для адміністрації Трампа існує ризик того, що співпраця 3 офіційним Каїром може зазнати репресивних тенденцій, поставивши американсько-єгипетські відносини на хиткий фундамент протягом послідуючих років» [13].

Слід зазначити, що Абдуль-Фаттах ас-Сісі став першим іноземним лідером, який привітав Дональда Трампа з його перемогою на президентських виборах. Для Д. Трампа президент АРЄ Cici $є$ взірцем безкомпромісного лідера, який прийшов до влади шляхом повалення авторитету «Братів мусульман», i який завзято бореться з проявами тероризму на півночі Синайського півострову та на кордоні 3 Лівією. В свою чергу, для Сici, президент Д. Трамп здається лідером, який на відміну від Б. Обами не зацікавлений у зловживанні добрими взаємини зі старим союзником заради ілюзорного захисту загальних прав людини. Окрім того, під час 
свого візиту до Вашингтону, що відбувся 3 квітня 2017 року, президент АРС запевнив нового американського лідера у тому, що він ж спроможнім виступати гарантом палестинсько-ізраїльського миру. Зі свого боку Дональд Трамп наголосив: «У Вас є чудовий друг і союзник в моєму обличчі. Я хочу, щоб усі знали, що ми дуже поважаємо президента Сici. Він зробив фантастичну роботу у вкрай складній ситуації» [14].

Попри такі гучні заяви залишається відкритим питання, чи вдасться президенту АРЄ Абдулю-Фаттаху ас-Сісі так вдало балансувати у трикутнику США - Арабський світ - Ізраїль, як це протягом понад 30-річного президентства робив Хосні Мубарак. І чи зможе він не повторити помилок іншого попередника, Гамаля Абделя Насера, який наприкінці свого лідерства, після очевидного зближення з Росією робив відчайдушні спроби відновити добрі взаємини з США.

\section{Література}

1. Egypt PM dismisses US aid threat over activists' trial [Electronic Resource]. - Mode of Access: http://www.bbc.com/news/world-middle-east-16949846 (Last Access: 8 February, 2012). - Title from the Screen.

2. In quotes: reaction to Egypt protest [Electronic Resource]. - Mode of Access: http://www.bbc.com/news/world-middle-east-12316019 (Last Access: 30 January, 2011). - Title from the Screen.

3. Egypt unrest: NGO offices raided in Cairo [Electronic Resource]. - Mode of Access: http://www.bbc.com/news/world-middle-east-16357795 (Last Access: 29 December, 2011). - Title from the Screen.

4. Foreign NGO workers reach Cyprus after leaving Egypt [Electronic Resource]. - Mode of Access: http://www.bbc.com/news/world-middle-east-17226779 (Last Access: 2 March, 2012). - Title from the Screen.

5. Hall M. Transition could weaken U.S. anti-terror efforts [Electronic Resource]. - Mode of Access: http://usatoday30.usatoday.com/news/washington/2011-02-04-terror04_ST_N.htm (Last Access: 2 April, 2011). - Title from the Screen.

6. Boyer D. Obama congratulates Morsi on winning Egyptian presidency [Electronic Resource]. Mode of Access: https://www.washingtontimes.com/news/2012/jun/24/obama-calls-to-congratulatemorsi-an-islamist-on-w (Last Access: 24 June, 2012). - Title from the Screen.

7. Fleishman J. (2012) In Egypt, Hillary Clinton offers support for Islamist president [Electronic Resource]. - Mode of Access: http://articles.latimes.com/2012/jul/15/world/la-fg-egypt-clinton20120715 (Last Access: 15 July, 2012). - Title from the Screen.

8. Obama: Egypt is not US ally, nor an enemy [Electronic Resource]. - Mode of Access: http://www.bbc.com/news/world-middle-east-19584265

(Last Access: 13 September, 2012). - Title from the Screen.

9. Mohsen M. Health Ministry raises death toll of Wednesday's clashes to 638 [Electronic Resource]. Mode of Access: https://www.webcitation.org/6Iz4po5fD?url=http://www.dailynewsegypt.com/2013/08/16/healthministry-raises-death-toll-of-wednesdays-clashes-to-638 (Last Access: 19 August, 2013). - Title from the Screen.

10. US unlocks military aid to Egypt, backing President Sisi [Electronic Resource]. - Mode of Access: http://www.bbc.com/news/world-middle-east- 27961933 (Last Access: 22 June, 2014). - Title from the Screen.

11. US resumes strategic dialogue with Egypt [Electronic Resource]. - Mode of Access: http://www.aljazeera.com/news/2015/08/kerry-egypt-strategic-dialogue-aje-150802163734101.html (Last Access: 2 August, 2015). - Title from the Screen.

12. Readout of the President's Call with President al-Sisi of Egypt. The White House. Office of the Press Secretary [Electronic Resource]. - Mode of Access: https://obamawhitehouse.archives.gov/thepress-office/2015/03/31/readout-president-s-call-president-al-sisi-egypt (Last Access: 31 March, 2015). Title from the Screen.

13. Benaim D. Setting the Terms for U.S.-Egypt Relations. Center for American Progress [Electronic Resource]. $\quad-\quad$ Mode of Access: 
https://www.americanprogress.org/issues/security/reports/2017/02/21/426654/setting-the-terms-for-u-segypt-relations (Last Access: 21 February, 2017). - Title from the Screen.

14. Visiting Sissi says Trump can solve Israeli-Palestinian conflict [Electronic Resource]. - Mode of Access: https://www.timesofisrael.com/visiting-sissi-says-trump-can-solve-israeli-palestinian-conflict (Last Access: 3 April, 2017). - Title from the Screen.

\section{References}

1. Egypt PM dismisses US aid threat over activists' trial (2012) [Online]. Available from: http://www.bbc.com/news/world-middle-east-16949846 [Accessed: 8 February, 2012].

2. In quotes: reaction to Egypt protest (2011) [Online]. Available from: http://www.bbc.com/news/world-middle-east-12316019 [Accessed: 30 January, 2011].

3. Egypt unrest: NGO offices raided in Cairo (2011) [Online]. Available from: http://www.bbc.com/news/world-middle-east-16357795 [Accessed: 29 December, 2011].

4. Foreign NGO workers reach Cyprus after leaving Egypt (2012) [Online]. Available from: http://www.bbc.com/news/world-middle-east-17226779 [Accessed: 2 March, 2012].

5. HALL, M., WOLF, R. (2011) Transition could weaken U.S. anti-terror efforts [Online]. Available from: http://usatoday30.usatoday.com/news/washington/2011-02-04-terror04_ST_N.htm [Accessed: 2 April, 2011].

6. BOYER, D., KUMAR SEN, A. (2012) Obama congratulates Morsi on winning Egyptian presidency [Online]. Available from: https://www.washingtontimes.com/news/2012/jun/24/obama-callsto-congratulate-morsi-an-islamist-on-w [Accessed: 24 June, 2012].

7. FLEISHMAN, J. (2012) In Egypt, Hillary Clinton offers support for Islamist president [Online]. Available from: http://articles.latimes.com/2012/jul/15/world/la-fg-egypt-clinton-20120715 [Accessed: 15 July, 2012].

8. Obama: Egypt is not US ally, nor an enemy (2012) [Online]. Available from: http://www.bbc.com/news/world-middle-east-19584265

[Accessed: 13 September, 2012].

9. MOHSEN, M. (2013) Health Ministry raises death toll of Wednesday's clashes to 638 [Online]. Available from:

https://www.webcitation.org/6Iz4po5fD?url=http://www.dailynewsegypt.com/2013/08/16/healthministry-raises-death-toll-of-wednesdays-clashes-to-638 [Accessed: 19 August, 2013].

10. US unlocks military aid to Egypt, backing President Sisi (2014) [Online]. Available from: http://www.bbc.com/news/world-middle-east- 27961933 [Accessed: 22 June, 2014].

11. US resumes strategic dialogue with Egypt (2015) [Online]. Available from: http://www.aljazeera.com/news/2015/08/kerry-egypt-strategic-dialogue-aje-150802163734101.html [Accessed: 2 August, 2015].

12. Readout of the President's Call with President al-Sisi of Egypt. The White House. Office of the Press Secretary (2015) [Online]. Available from: https://obamawhitehouse.archives.gov/the-pressoffice/2015/03/31/readout-president-s-call-president-al-sisi-egypt [Accessed: 31 March, 2015].

13. Benaim, D., AWAD M. \& Katulis, B. (2017) Setting the Terms for U.S.-Egypt Relations. Center for American Progress [Online]. Available from: https://www.americanprogress.org/issues/security/reports/2017/02/21/426654/setting-the-terms-for-u-segypt-relations [Accessed: 21 February, 2017].

14. Visiting Sissi says Trump can solve Israeli-Palestinian conflict (2017) [Online]. Available from: https://www.timesofisrael.com/visiting-sissi-says-trump-can-solve-israeli-palestinian-conflict [Accessed: 3 April, 2017].

Надійшла до редколегії 25.08.2017

Irina Zubarenko, $\mathrm{PhD}$ (history), Associate Professor, Iliya Mechnikov National University of Odessa, Odessa

\section{THE AMERICAN-EGYPTIAN RELATIONS AFTER THE ARABIC SPRING}

Abstract. The article touches upon the development of American-Egyptian relations after the Arab Spring that took place in the winter of 2010 and led to the changes in the political, economic and social situation in the Arab Republic of Egypt. 
Egypt is the most densely populated Arabic country. And although it is still unable to play a leading role in the Arab world, Egypt still remains an influential country in the region due to its historical heritage.

The current administration of the United States has expressed great hopes for the American-Egyptian relations that have suffered from some serious tensions. However, there is a risk that cooperation with the official Cairo might be repressive, placing US-Egyptian relations at a shaky foundation over the next few years.

The article covers the author's vision of the events on the basis of the original sources, which have been mostly presented by those in the Western press. The article is therefore generally based on a chronological analysis of the situation that took place in the history of relations between the two countries. Despite the fixed historical facts published in the context of certain events, the author keeps her own right on the analysis of the abovementioned events.

Key words: Arab Spring, American-Egyptian relations, president, democracy, elections, Egypt, the USA.

\title{
УДК 94:327 (73)
}

Gunel Musayeva, Ph.D (history)

Institute of the Caucasus Studies, ANAS, Baku Republic of Azerbaijan

\section{THE ROLE OF THE USA IN THE IMPLEMENTATION OF THE PROJECT BAKU-TBILISI-CEYHAN}

\begin{abstract}
After the signing of the contract of the century in 1994, the itineraries for new routes to transport the energy resources of Azerbaijan, a country without direct access to the ocean, has been the subject of fierce debate against the backdrop of the geopolitical interests of the world's major powers. While the construction of the Baku-Batumi oil pipeline in the early $20^{\text {th }}$ century was a challenge of a technological nature, this time the main "gamble" was geopolitical. The article therefore considers choosing of alternatives of true transport routes and an impact of the USA thereupon. The BTC project is the first comprehensive project aimed at changing the status quo in the region; the latter being the only alternative route to export oil out of the region, the Russian route to Novorossiysk. Since 1993, Russia, which is still the most notable power in Central Asia and Caucasus, did its utmost to keep the region under its uncontested influence by utilizing every possible political, economic and military instrument within the framework of its popular "Near Abroad" doctrine. For the first time, Russia's monopoly over oil export routes from the Caspian region has been broken. This article also analyses the course of events that led to the realization of the BTC pipeline where an American policy played an important role.
\end{abstract}

Key words: USA, Baku-Tbilisi-Ceyhan oil pipeline, American policy, BP, Caucasus, project.

The contract of the century provided for the transport of crude oil in two phases: the search for a solution for the transport of early oil, and the selection of the main export pipeline [14, p. 109].

SOCAR had announced the existence of three options: north (Russia), south (Iran) and west (Turkey). The first option (north) was favoured by Moscow, but due to instability in the North Caucasus, the consortium members demanded guarantees in relation to Chechen territory. The AIOC (Azerbaijan International Operating Company) evaluated the risk of interruptions to the transport of Azeri crude oil and feared being 